\title{
Discussion on Workshop-style Teaching Mode of Soft Decoration Design Course in Higher Vocational Colleges*
}

\author{
Zhaohui He \\ Xiamen Xingcai Vocational \& Technical College \\ Xiamen, China
}

\begin{abstract}
At present, it has been the urgent task for vocational colleges to accelerate the development of modern vocational education and the cultivation of "craftsmanship" vocational talents with high skills and high quality along with the proposing of "conversion from Made in China to Created in China, from China Speed to China Quality, from China Products to China Brands". As for how to cultivate craftsmanship talents, some colleges in China adopt the concept of "workshop" of Bauhaus to teach, and some "studio system" teaching modes with disciplinary characteristics have emerged. Some higher vocational colleges, such as Shenzhen Polytechnic, Ningbo Polytechnic, have made attempts in studio teaching reform with certain achievement gained. However, the teaching mode of cultivating "craftsmanship" soft decoration talents has encountered its bottleneck due to late starting, rapid development and growing market demand of soft decoration design in China. The workshop teaching mode is put forward to try to solve problems facing by soft decoration design course in higher vocational colleges through analysis of Bauhaus workshop-style teaching mode and the experience of studio-type teaching modes of some excellent colleges that have acquired substantial achievements in combination with current economic development trend and the characteristics of soft decoration design industry itself.
\end{abstract}

Keywords-higher vocational college; soft decoration design; workshop-style

\section{INTRODUCTION}

As an emerging industry, soft decoration design develops rapidly in recent years, and tends to have a quality- and lifeoriented development along with the improvement of Chinese people's economic level and living standard. Higher vocational colleges are the main force for the cultivation of talents in terms of technology, service and management for the front line of social industrial production. The soft decoration design of most colleges hasn't separated from the major of interior design due to lagging education. The studio system passed on to China since the 1980s-1990s is adopted as the teaching mode. In the Nineteenth National Congress of the Communist Party of China, the concepts of promoting the moderately prosperous society in an all-round way, accelerating construction of manufacturing power and "craftsman of great

*Fund Project: Project of Xiamen Educational Science "Thirteenth-five Year" Plan 2017. Project No.: 1735. power" were proposed, which imposed new requirements for the soft decoration design industry. It is an issue to be solved urgently by current high vocational colleges as how to cultivate the high-technology and high-quality talents and craftsmen of soft decoration design for social and economic transformation development, and the teaching mode adopted by it plays an essential role.

\section{CURRENT SitUATION OF "WORKSHOP-STYLE" TEACHING MODE}

\section{A. In Foreign Countries}

Workshop-style teaching mode refers to the teaching method that "apprentice" learns a craft or skill in workshop or factory under direct guidance of master, and it is proposed by Professor Gropius of Germany Bauhaus School of Design. In 1919 , the craft articles were produced in large quantity by machine with the impact of the great industrial revolution, and the capitalists pursued only quantity while neglecting artistic creation. As a result, Bauhaus School of Design was established in Weimar, Germany. "Artistic creation is the soul of artistic products, and the absent of which means the declining of human civilization" [1]. With such clear schoolrunning positioning, the workshop-style teaching mode was formed in Bauhaus School of Design with three distinct features: First, creating the concept of "stressing the role and operation skills of workshop" [2], to complete handicraft training through workshop. Third, students have to study the primary courses for half a year after enrolment, and then accept the handicraft training while studying the theological course. The qualification of "craftsman" will be obtained if the examination is passed three years later. Fourth, it "combines education in school with social demand and enterprise production"[3]. This mode enables students to master various production technologies and skills, improves students' ability of actual situation, and displays the teaching achievements directly in the form of products, producing economic benefits and realizing the integration of teaching, research and practice. A large number of artistic "famous craftsmen" and "masters" at international level are cultivated in many European countries under such teaching mode, and many well-known high-end brands are created, for instance, the famous foreign brands those Chinese people madly cling to, including Chanel, Louis Vuitton and Dior, are originated from the traditional workshop discarded by modern people. 


\section{B. In China}

The workshop-style teaching mode has long been existed in China since ancient times. "Jiu Tang Shu - Biography of Qi $\mathrm{Fu}$ records that, "the rebellion in western areas is put down, and the people of these areas are distributed to the workshop as slaves and maid-servants. Fu ordered to visit their relatives and permitted them all to return." "Zi Zhi Tong Jian - Third Year of Qianyou of Emperor Yin in Late Han Dynasty records that, '[The emperor] often hears the sound of forging from workshop in the night, and cannot fall asleep all night as he suspects there must be urgent military affairs.' Hu Sansheng offered the note that, 'workshop is the place for manufacturing military weapons; workshop makes a country in leading position.' In Hai Shang Shu Lin - Replay of Qu Qiubai during the period of Republic of China, 'half of the beggar-like equipment factory and workshop are destroyed by the civil war." [4] "Workshop" is mentioned in all of these books. Up to now, such teaching mode still exists in some family workshops and factories in China, most of them are dominated by handicraft, for instance, Jingdezhen Ceramic Institute and Suzhou Embroidery. After the reform and opening up, China experiences the rapid economic development, the supply of high-tech talents fails to meet the demand, and the craftsmanstyle workshop teaching mode is almost lost. Currently, workshop teaching mode is put into the agenda once again along with the advancement of "Created in China" and the return of craftsman spirit. Some institutes of fine arts and the design major of comprehensive colleges introduce in "workshop" teaching method from foreign countries, and start to research "studio system" with disciplinary characteristics according the actual condition of the college, for instance, Central Academy of Fine Arts, Hunan University, etc. In the field of vocational education, Wuxi Vocational Institute of Commerce, Zhejiang Business Technology Institute and Ningbo City College of Vocational Technology also adopt "studio system" teaching mode to carry out teaching reform, and outstanding achievement has been achieved. However, in the development process of different majors of different schools, there are also some problems, which are mainly reflected in the following aspects:

- Shortage of teachers, skilled craftsmen or masters.

- There are too many students in the studio, which are generally twenty to thirty and even more. Although it satisfies current factory-type production demand of interior design industry, it nips students' creativity, making students the machine of drawing, and it is hard to achieve the teaching process of taking the student by the hand and teaching him how to do.

- Students generally have sufficient loyalty to profession, and are short of craftsman spirit.

- Inadequate cooperation between school and enterprise, and the assessment standard of local industrial recognition or acquisition of "craftsman" qualification has not yet been established.

Generally speaking, the theoretical research and practical application of workshop-style teaching mode in China is still in the preliminary stage of exploration, and is short of systemic theoretical and practical framework.

\section{CURRENT SituATION AND DEVELOPMENT TREND OF CHINA'S SOFT DECORATION DESIGN INDUSTRY}

In recent years, as a newly emerging industry, "soft decoration design" is constantly seen in the media and talked by the masses, and various posts relating to soft decoration design have become the new hot spot in the professional area. "According to the statistics of China Furniture \& Decoration Chamber of Commerce, currently, China's home furnishing value has been more than 1 trillion yuan, and it grows at the speed of $20 \%$ each year" (5). In the Nineteenth National Congress of the Communist Party of China, "the conflict between people's increasing demand of happy life and the unbalance, insufficient development" was proposed as China's main contradiction, indicating that people's requirement of space soft decoration is no longer the basic functional demand, but the higher pursuit and expectation of the culture, individuality, interest, beauty and quality of soft decoration products. The task of soft decoration design has developed to manufacturing product, design product and innovative product from the simple selling communities from the very beginning. "Individualize customer-tailor, soft production", and "increase varieties, enhance quality and create brand." In the new era, more talents with craftsman spirit, serving with humanities and explaining with motion are required for the soft decoration market.

In the current artistic education context in China, soft decoration design course is a course of interior design major, which is also called soft decoration or interior display design, and it is the interior decoration form relative to traditional "hard decoration", namely the secondary decoration of the changeable and updatable furniture, fabric art, curtain, plant, iron art, paintings and blankets hanging on the wall after interior decoration is completed.

IV. RESEARCH AND PRACTICE OF "WORKSHOP-STYLE" TEACHING MODE OF SOFT DECORATION DESIGN COURSE IN Higher Vocational COLLEGES

\section{A. Reasons of Well-operated Workshop-style Teaching Mode} in Western Countries

- The industrialized workshop teaching inserts the craft manufacturing and training into the workshop on campus, adopts the master-apprentice system to enable students to study while practicing, aiming to require students to master the basic knowledge and skills required by all industrial production. Generally, one master can teach up to 10 apprentices in the workshop, and each student must grasp a kind of craft after completion of the study. Such organization form with small number of students in a class has guaranteed real-time interaction between teacher and students, ensured high quality of talents and improved education cost with high teacher-student ratio.

- Double-track employment. The workshop of Bauhaus consists of masters, experienced works and apprentices. Bauhaus employs two kinds of supervisors, namely the supervisor of form and 
supervisor of studio, among them, the supervisor of studio shall be craftsman. Under such double-track employment system, the position of craftsman is as high as that of artist, playing a great role in carrying forward the importance of technology, promoting practice and creation, and guaranteeing high-quality teaching.

- Connecting to market. It combines teaching content and enterprise production. In the workshop, there is real industrial production, and students have their own income for tuition fee allowances. The workshop teaching adopting certain characteristics of industrial organizational system and the basic form of design companies can achieve the process and achievement of industrial design directly and quickly.

In a word, Bauhaus workshop-style teaching mode breaks the fence of artistic education, lays foundation for the chain social service of art-design-production, and provides the scientific teaching mode that can be followed for the theoretical conversion of artistic design students.

\section{B. Exploring and Establishing the Workshop-style Teaching Mode Theoretical System of Soft Decoration Design Course Based on Craftsman Spirit}

At present, only a small part of colleges open the soft decoration design course due to the lagging development of higher vocational colleges, so curriculum system is not perfect or systematic enough; the studio system is applied mechanically for the teaching mode. Soft decoration design is the integration of art and technology. The abovementioned problems existing in studio system teaching indicate that, the teaching of studio system can no longer satisfy the demand of soft decoration design in terms of transforming life style, designing individualized products and craftsman service. The exploration, construction and implementation of the workshop teaching mode of higher vocational college soft design course that conforms to the higher vocational education law and the artistic design education law, is of theoretical significance and practical value for the cultivation of higher vocational soft decoration design talents with strong practical ability and the ability of innovation and starting a business. No matter the "workshop-style teaching mode" of artistic design major of Bauhaus School, or China's traditional "small workshop", such teaching mode is an effective method for the current soft decoration design that pursues artistic creation.

1) Introducing enterprise into colleges and establishing workshop jointly, constructing work-oriented courses: First, introducing enterprises into colleges. "Introducing enterprises into colleges" refers to the integration of resources by the enterprise and with advantage complementary, and they carry out professional teaching and enterprise production, and form the relationship of mutual dependence, mutual promotion and mutual benefit. The basic characteristics of this mode are as follows: college cooperates with enterprise and establish enterprise workshop in the college jointly, making the office and production department of the enterprise as the training base of the college; they implement the enterprise operation, take production and operation as the major task, take professional teaching into consideration, conduct parallel operation of production and teaching, and give full play to the role of vocational colleges in promoting economic development. This mode is an effective method for establishing sustainable long-acting mechanism of schoolenterprise cooperation. For instance, with respect to soft decoration design, the operation of a normal soft decoration design company in current market requires financial department, marketing department, design department, construction department, and after-sale service department and so on. The colleges, however, can only cultivate students to complete the tasks of design department and construction department due to lack of experienced workers and skilled craftsmen. Actually, only a small number of students can be competent to the task of construction department, most of them are still in the stage of experiment, with their works cannot be put into market to generate economic benefits. In addition, students are still in the stage of studying in school, without contacting to the society, or the awareness of survival or competitive crisis, so it is difficult for them to complete the design works or project or to realize its sustainable development due to lack of concentration, perseverance and pressure resistance, namely lack of the craftsman spirit, though they have interest in production and creation of works. By introduction of enterprise into college, the college and enterprise can establish workshop jointly, distribute the enterprise personnel, teachers and students to different departments according to the organization of the enterprise, and manage students pursuant to enterprise regulations, to realize school-enterprise integration and integrated teaching.

Second, establishing workshop jointly. The workshop is made up of enterprise experts, experienced workers, teachers (enterprise management personnel, employees), and students (apprentices, employees), with the enterprise experienced technicians and skilled craftsmen are both the enterprise experts and the master of "workshop". The enterprise may select talents from the sophomore majored in interior design as the apprentices required by the company according to its own selection requirement, and some more students can be selected to keep in reserve. Rules and regulations for "workshop" management and remuneration should be formulated in accordance with industrial standard. The site for establishing workshop is provided by the college, with no need for the enterprise to pay rent, charges for water and electricity, network fee, etc. Enterprise shares resources with college, and enterprise assumes teaching and practice together with teachers, to lead students to shoulder social service project jointly, with the obtained funds being shared between them.

Third, establishing work-oriented courses. After the enterprise is introduced in the college, the enterprise will land in the college "workshop" directly, and construct workoriented soft decoration design course and curriculum system for innovation and starting a business according to the target of cultivating excellent soft decoration design talents, and based on the sustainable development ability and accomplishment requirements of the staff. The professional course is divided 
into two levels: namely professional platform course and post guidance course. The course task will be arranged against the project task, or the teaching will be arranged according to ordered quantity, task and time. In other words, to attend class is to work. The students cultivated by them can produce economic benefits directly for the company. The course for innovation and starting a business is to integrate the education of innovation and starting a business into the course of soft decoration design practice, to go forward gradually and to connect organically, so as to strengthen students' spirit, personality and ability of innovation.

2) Double-track teaching in small classes or groups by craftsmen and teachers: The workshop teaching mode is carried out in small groups, in which teachers and students complete the task jointly under the guidance of enterprise experts and experienced technician, which is small-class teaching. Small-class teaching is one the characteristics of workshop teaching mode. As we all know, a company will not keep employees who do not work, as it only supports the personnel who creates benefits for the enterprise; therefore, to satisfy enterprise benefits, the workshop should be constructed according to the number of personnel required by the company to offer small-class teaching. Being able to stay in such workshop through selection and competition, each student is filled with pressure and challenge, which will mobilize students' enthusiasm and enable students to experience the real work, to recognize the survival law of selecting the superior and eliminating the inferior, so as to achieve the seamless connection of occupational spirit, professional skill and social post. Furthermore, small-class teaching can satisfy the teaching method of skilled craftsmen or masters, namely to teach by doing in the workshop. In this way, the masters can impart their own experience and skills to the apprentices, and in turn, apprentices can get the real technology, thus their sense of occupational happiness is increased.

3) Inheriting originality, incubating innovation, designing production, and creating brand: The workshop teaching mode implements the teaching method of originality inheritance. In China, the master-apprentice relation is subtle, as they are not father and son, but as intimate as father and son. The master conveys patience, originality and craftsman spirit while imparting skills. Students and apprentices sign an agreement with the master to make clear the obligations and responsibilities, and specify the incentive and constraint mechanism, to ensure the inheritance of skill and spirit in an effective way. To carry out the teaching or work between master and apprentice by agreement, the apprentices can learn many "unique techniques" from the master in a solid way. In addition, being imbued with what they had seen and heard in the course of learning from the teachers, students can understand teachers' pursuit of perfect skill and their concentration and perseverance of occupational spirit. Enterprise experts and the college backbone teachers will ultimately create the soft decoration design brand with cultural connotation and quality while jointly researching courses, developing projects, innovating design, producing products, serving the society and satisfying customer demand.

The workshop teaching mode provides a method for the soft decoration design of higher vocational colleges as how to cultivate "craftsman" talents, offers talent guarantee for the development of regional soft decoration industry, pushes the middle- and high-end development of regional soft decoration industry, so as to drive the development of the whole design industry.

\section{Problems Needing Attention in the Workshop-style Teaching Mode of Soft Decoration Design in Higher Vocational Colleges}

Higher vocational colleges cultivate the service, technology and management talents for the front line of production. Therefore, the construction and implementation of workshop teaching mode of soft decoration design course should conform to the regional economic development trend by taking the advantages of existing regional industry. Furthermore, adequate training equipment and long-term cooperation experience with local industry and enterprise are also required to establish the famous master studio consists of enterprise experts, experienced craftsmen in the industry and the college backbone teachers. Effective operation mechanism with mutual benefit among enterprise, college and students should be worked out, so as to guarantee teaching quality and promote students' sustainable development.

\section{CONCLUSION}

To sum up, workshop-style teaching mode is beneficial to cultivating students' studying atmosphere, arousing their interest in learning, strengthening their occupational accomplishment, and cultivating their ability of actual practice, innovating and starting a business. As a result, the introduction of workshop-style teaching mode into soft decoration design course of higher vocational colleges is an effective attempt beyond doubt.

\section{REFERENCES}

[1] Xu Aijun, Jiang Xinge. Connotation and Concept Analysis of Studio Teaching Mode $[\mathrm{J}]$. Chinese Occupational and Technical Education, 2016 (11)

[2] Compiled by Yao Mingyi. Overview of Modern Design Education in Germany - from the $20^{\text {th }}$ century to the $21^{\text {st }}$ century. [M] P15

[3] Chinese Decoration. [M] Vol. I, p1249, scan version

[4] Wang Hong, Liu Jie. Reflection on Dissemination Conveyed by Soft Decoration Design Culture [J]. Beauty and Times (middle), 2015 (05) 